\title{
AN OVERVIEW OF RECENT DEVELOPMENTS IN THE POLYURETHANE INDUSTRY
}

\author{
KURT C. FRISCH*
}

\section{INTRODUCTION}

The polyurethane industry has grown from its start in the 1930 s to almost 6 million tons worldwide ${ }^{1)}$. What makes polyurethanes so unique among the commercial polymers is their use in 15 major industries with new markets and new products and applications growing constantly.

However, with this phenomenal growth of the polyurethane industry, particularly in the last twenty years, major challenges have arisen which are of considerable concern to this industry. They can be categorized as follows, though not necessarily in the order of importance:

(1) Elimination of CFCs in polyurethanes;

(2) Fire safety-lowering combustibility and smoke evolution in polyurethane products;

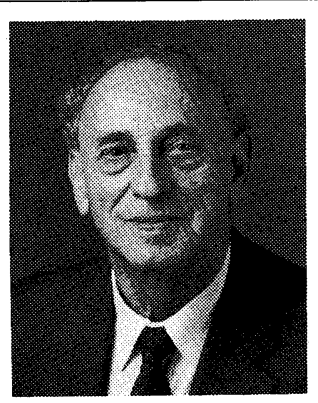

*デトロイト大学 PTI

(Polymer Technologies, Inc., 4001 W. McNichols Rd., Detroit, Mich., 48221-3090 U.S.A.) 社長 兼研究所長. デトロイト 大学化学工学科, 及び化 学科教授. Vienna大学, Brussels 大学卒業. コロ ンビア大学で Ph.D. 取 得(1944年). GE 社, E. F. Houghton 社に勤務. 1956 年から1968年まで Wyandotte Chemicals (現 BASF) 社の高分子 R \& $\mathrm{D}$ 担当取締役. 1984 年 SPI (プラスチック工業 協会) ポリウレタン殿堂 入り.
(3) Insuring health and safety in the manufacture and applications of polyurethanes; and

(4) Recycling and utilization of waste materials and safe disposal of waste products including incineration for energy generation.

\section{THE CFG REPLACEMENT CHALLENGE}

In 1974, two American scientists, Rowland and Molina, published their now famous ozone-depletion hypothesis in which they claimed that CFGs would diffuse into the stratosphere where they would break down to release chlorine atoms which would catalytically destroy ozone. This in turn would lead to an increase in UV-B radiation in the $290-320 \mathrm{~nm}$ region at the earth's surface, with consequent implications for human health and other biological systems.

A great deal of efforts throughout the polyurethane industry worldwide is currently in the replacement of CFCs by alternate blowing agents. The deadlines set by the Montreal Protocol, and later accelerated by the London Conference, made this task even more imperative. The most obvious approach for an alternate blowing agent to $\mathrm{CFC}-11$ in rigid $\mathrm{PU}$ foams is $\mathrm{CO}_{2}$ obtained by reaction of isocyanate with water. However, the $\mathrm{k}$ factor of $\mathrm{CO}_{2}$ blown foams, both initial and aged, is quite a bit higher than that of CFC-11 blown foams. Hence, combinations of water with CFC-11, and later with HCFCs, have led to lower thermal conductivity, as compared to that of only water blown foams. The next ob- 
vious approach was to replace CFCs, especially CFC-11 and CFC-12, by HCFCs. The presence of hydrogen in the molecule provides a mechanism for destroying the molecule in the lower region of the atmosphere (the troposphere), before it reaches the stratosphere and can release chlorine through photolysis. The fully halogenated CFCs have much greater atmospheric lifetimes as their only removal mechanism is photochemical destruction in the stratosphere.

Tropospheric destruction or removal of the hydrochlorofluorocarbons is, achieved through reaction with the hydroxyl radical, $-\mathrm{OH}$, present as a trace component in the troposphere.

$$
\mathrm{R}_{(\mathrm{R}+\mathrm{Cl})} \mathrm{H}+-\mathrm{OH} \stackrel{-\rightarrow \mathrm{R}}{(\mathrm{R}+\mathrm{Cl})}+\mathrm{H}_{2} \mathrm{O}
$$

This reaction essentially reduces the atmospheric lifetime of the molecule and consequently reduces the ozone depletion potential of the molecule. When the reaction occurs very rapidly, the atmospheric lifetime of the molecule is very short, which in turn may lead to another type of environmental problem, namely, photochemical pollution in the lower atmosphere. The volatile organic compound (VOC) status of the CFC substitutes is being considered by the EPA.

The magnitude of ozone depletion potential is dependent on, from amongst a number of factors, the amount of chlorine in the molecule, the rate of reaction with $-\mathrm{OH}$, the concentration of $-\mathrm{OH}$ present in the atmosphere, and the photochemical lifetime of the fluorocarbon in the stratosphere. The first two factors determine the lifetime of the molecule in the troposphere, while the latter defines the altitude at which those molecules, which have survived tropospheric destruction, are broken apart by ultra-violet radiation and release chlorine in the stratosphere.

The existing CFCs and the substitute HCFCs are potential greenhouse gases. The atmospheric warming potential of the substitutes depends on their atmospheric lifetimes/both HCFC-123 and HCFC-141b have significantly lower greenhouse warming potentials due mainly to their much shorter atmospheric lifetimes. A comparison of some physical properties of CFCs with potential HCFC candidates, along with their respective ozone depletion factor (ODP) is shown in Table $1^{2)}$.

Extensive work has been carried out and commercial systems have been developed using HCFC-123 ad HCFC-141b. Their boiling points are fairly close to that of $\mathrm{CFC}-11$, but, despite this fact, considerable work had to be carried out to develop suitable formulations using either HCFGs alone, in combination with each other as well as in combination with water. Due to recent findings in toxicological tests, HCFC-123 is being gradually replaced by $\mathrm{HCFC}-141 \mathrm{~b}$ in many formulations.

Chlorodifluoromethane (HCFC-22) can be considered a short term option for complete substitution of CFC-11.

$\mathrm{BASF}^{3)}$ has reported the use of chlorodifluoromethane (HCFC-22) for use in rigid $\mathrm{PU}$ foams using conventional low and

Table 1 Physical properties of hard CFCs and their possible substitites.

\begin{tabular}{|c|c|c|c|c|c|c|c|c|c|}
\hline & $\begin{array}{c}\text { CFC } \\
-11\end{array}$ & $\begin{array}{l}\text { CFC } \\
-12\end{array}$ & $\begin{array}{c}\text { HCFC } \\
-123\end{array}$ & $\begin{array}{l}\text { HGFG } \\
-141 \mathrm{~b}\end{array}$ & $\begin{array}{c}\text { HCFG } \\
-22\end{array}$ & $\begin{array}{c}\text { HCFC } \\
-124\end{array}$ & $\begin{array}{l}\text { HFC } \\
-134 \mathrm{a}\end{array}$ & $\begin{array}{l}\text { HCFC } \\
-142 b\end{array}$ & $\begin{array}{c}\mathrm{HFC} \\
-152 \mathrm{a}\end{array}$ \\
\hline Formula & $\mathrm{CCl}_{3} \mathrm{~F}$ & $\mathrm{CCl}_{2} \mathrm{~F}_{2}$ & $\mathrm{CF}_{3} \mathrm{CHCl}_{2}$ & $\mathrm{CH}_{3} \mathrm{CCl}_{2} \mathrm{~F}$ & $\mathrm{CHClF}_{2}$ & $\mathrm{CF}_{3} \mathrm{CHCF}$ & $\mathrm{CF}_{3} \mathrm{CH}_{2} \mathrm{~F}$ & $\mathrm{CH}_{3} \mathrm{CClF}_{2}$ & $\mathrm{CH}_{3} \mathrm{CHF}_{2}$ \\
\hline $\begin{array}{c}\text { Molecular } \\
\text { Weight }\end{array}$ & 137.4 & 120.9 & 152.9 & 117.0 & 86.5 & 136.5 & 102.0 & 100.5 & 66 \\
\hline $\begin{array}{l}\text { Boiling } \\
\quad \text { Point }\left({ }^{\circ} \mathrm{C}\right)\end{array}$ & 23.8 & -29.8 & 27.9 & 32 & -40.8 & -11 & -26.5 & -9.2 & -24.7 \\
\hline ODP & 1 & 1 & 0.02 & 0.1 & 0.05 & 0.02 & 0 & 0.06 & 0 \\
\hline
\end{tabular}


high pressure mixing equipment. However, due to the low boiling point of HCFC-22 (b.p. $-40^{\circ} \mathrm{C}$ ), a special set-up for the addition of HCFC-22 is required consisting of a series of valves, a metering valve, a check valve, and a shut-off valve with a pressure gauge attached. Once the desired level of HCFC-22 has been added, the machine can be run normally. Low density foams (ca. $24 \mathrm{~kg} / \mathrm{m}^{3}$ ) with excellent dimensional stability and good physical properties can be obtained using HCFC-22 as well as in combination with water. Their $\mathrm{k}$ factors, versus those of all-water blown foams, were improved, and the aged $\mathrm{k}$ factors were $15-17 \%$ reduced with $\mathrm{HCFC}-22 / \mathrm{H}_{2} \mathrm{O}$ versus those of all water blown foams.

Pentane is enjoying some attention as an alternative blowing agent in Scandinavia and Germany. There is no ozone depletion potential, but pentane forms explosive mixtures with air between $1.4 \%$ and $7 \%$ by volume. Its use results in loss in thermal conductivity. Ashida et al (Polymer Technologies, Inc--University of Detroit Mercy) has employed a combination of pentane and methylene chloride as an efficient blowing agent system for the production of rigid polyurethane foams.

At the 1990 UTECH Meeting, Schutz of Hoechst ${ }^{4)}$ reported the possibility of using hydrofluorocarbons, such as $\mathrm{HFC}-134 \mathrm{a}\left(\mathrm{CH}_{3}-\right.$ $\mathrm{CH}_{2} \mathrm{~F}$, b.p. $\left.-265^{\circ} \mathrm{C}\right)$ and $\mathrm{HFC}-227\left(\mathrm{CF}_{3}\right.$ $\mathrm{CHF}-\mathrm{CF}_{3}$, b.p. $-17.3^{\circ} \mathrm{C}$ ), but pointed out the change in processing due to the low boiling point of these HFGs. However, she proposed a third generation of CFC-substitutes of the general formulae: $\mathrm{C}_{m} \mathrm{H}_{n} \mathrm{~F}_{\mathrm{p}}$ and ethers of the general formula: $\mathrm{C}_{\mathrm{a}} \mathrm{H}_{\mathrm{b}} \mathrm{F}_{\mathrm{c}}-\mathrm{O}-\mathrm{C}_{\mathrm{d}} \mathrm{H}_{\mathrm{e}} \mathrm{F}_{\mathrm{f}}$.

Recticel $^{5)}$ has developed 2-chloropropane (b.p. $35.7^{\circ} \mathrm{C}$ ) as blowing agent for PU-insulation panels. Its ozone depleting value (ODP) is almost zero, but it is flammable. There is no special hazard as far as toxicological tests have shown. Extensive reformulation was required for the production of rigid foam boards. The
Table 2 Suitable perfluoroalkanes.

\begin{tabular}{cccc}
\hline Compound & M.W. & $\begin{array}{c}\text { Boiling Point } \\
\left({ }^{\circ} \mathrm{C}\right)\end{array}$ & $\begin{array}{c}\text { Vapour Pressure } \\
25^{\circ}(\mathrm{mbar})\end{array}$ \\
\hline $\mathrm{C}_{5} \mathrm{~F}_{12}$ & 288 & 29 & 625 \\
$\mathrm{C}_{6} \mathrm{~F}_{14}$ & 338 & 57 & 309 \\
$\mathrm{C}_{7} \mathrm{~F}_{16}$ & 388 & 80 & 105 \\
\hline
\end{tabular}

physical properties of these foam panels were very similar to those when CFC-11 was used. However, the thermal conductivity of the gas phase is higher than that of CFC-11, but remains lower than $\mathrm{CO}_{2}$ and air.

Bayer has developed a new chlorine-free hydrofluorocarbon blowing agent, namely 1,1,1,4,4,4-hexafluorobutane (HFB) ${ }^{6)}$. Since it is chlorine-free, it is not ozone depleting, it has a very short atmospheric lifetime, and hence, there is only minor greenhouse activity; it is non-flammable with a boiling point of $24.6^{\circ} \mathrm{C}$, very similar to that of CFC-11 (b.p. $23.8^{\circ} \mathrm{C}$ ), and has a low gas phase thermal conductivity. When using it as a "drop-in" replacement for $\mathrm{CFC}-11$ in a Bayer rigid PU foam formulation, while the initial thermal conductivity of the HFB-blown foam was slightly higher, the aged thermal conductivity was very similar or even slightly better than that of the CFC-11 blown foam. Toxicological testing must be carried out as well as notification before commercialization, since it is a new product. In addition, being a fluorine-based blowing agent, the costs will probably be high, and, hence, its use would be restricted to special applications.

Volkert of $\mathrm{BASF}^{7)}$ prepared rigid $\mathrm{PU}$ foams using emulsified perfluoroalkanes as blowing agents. The most suitable perfluoroalkanes were found to be perfluoropentane and perfluorohexane. Their boiling points and vapor pressures are shown in Table 2. Since perfluoroalkanes are insoluble in both polyols and polymeric isocyanates, foams cannot be produced by conventional methods. Therefore, a special procedure was developed 
Table 3 Formulation and properties of an emulsion foam.

\begin{tabular}{lrll}
\hline \multicolumn{2}{l}{ Formulation $(\mathrm{pbw})$} & \multicolumn{2}{c}{ Foam Properties } \\
\hline Polyl & 83.7 & Free-rise density & $27 \mathrm{~g} / l$ \\
Silicon & 2.3 & Moulded density & $35 \mathrm{~g} / l$ \\
Catalysts & 1.9 & Closed cells & $88 \%$ \\
Water & 3.8 & Cell diameter & $117 \mu \mathrm{m}$ \\
Per-F-Alkane & 8.3 & $\lambda_{0}$ & $18.1 \mathrm{~mW} / \mathrm{m}^{\circ} \mathrm{K}$ \\
MDI Undex & 110 & $\lambda\left(14 \mathrm{~d} / 80^{\circ} \mathrm{C}\right)$ & $21.6 \mathrm{~mW} / \mathrm{m}^{\circ} \mathrm{K}$ \\
\hline
\end{tabular}

for dispersing perfluoroalkanes in the polyol as emulsions whose fine droplets easily vaporize. The most suitable dispersing agent was the ester of a monohydric polypropylene glycol (ave. mol. wt. of about $700 \mathrm{~g} / \mathrm{mole}$ ) and perfluorobutyric acid:<smiles>CCCC(=O)OC(C)COC</smiles>

The formulation and foam properties of an emulsified foam is shown in Table 3. The thermal conductivity of this foam is surprisingly low. Since the costs of perfluoroalkanes are high, it is desirable to use as little as possible.

Combinations of perfluoroalkanes with water alone showed that while the thermal conductivity was low (less than $20 \mathrm{mWm}^{-1} \mathrm{~K}^{-1}$ ), the resulting foams exhibited brittleness and poor adhesion. However, when combinations with small amounts of pentane and water were used, as shown in Table 4, it resulted in a good balance of properties including low thermal conductivity. With about $1 \%$ of pentane, the fraction of perfluoroalkane in the foam could be reduced to less than $2 \%$, and the amount of water used was not enough to reduce adhesion. In addition, the amount of pentane was also low enough to avoid flammability problems. Since the proportion of perfluoroalkanes is reduced in these foams, any contribution to the greenhouse effect can be considerable negligible.
Table 4 Replacement of perfluoroalkane by pentane.

\begin{tabular}{|c|c|c|c|c|c|}
\hline \multicolumn{2}{|c|}{ Per-F-Alkane \% } & \multicolumn{2}{|c|}{$n$-Pentane $\%$} & \multirow{2}{*}{$\begin{array}{l}\mathrm{H}_{2} \mathrm{O} \\
\% \text { inA }\end{array}$} & \multirow{2}{*}{$\begin{array}{c}\lambda_{0} \\
\mathrm{~mW} / \mathrm{m}^{\circ} \mathrm{K}\end{array}$} \\
\hline In $A$ & In Foam & In $\mathrm{A}$ & In Foam & & \\
\hline 8.3 & 3.3 & 1.8 & 0.7 & 3.4 & 18.4 \\
\hline 6.5 & 2.6 & 2.2 & 0.9 & 3.4 & 18.7 \\
\hline 4.8 & 1.9 & 2.7 & 1.1 & 3.4 & 19.0 \\
\hline 2.9 & 1.2 & 3.1 & 1.2 & 3.4 & 19.8 \\
\hline
\end{tabular}

\section{NEW FOAM DEVELOPMENTS}

In 1990, the total world production of motor vehicles amounted to 48.8 million. 380,000 tons of molded flexible foam was used in the manufacture of the cushioning material for seats in these vehicles ${ }^{8)}$. The type of foam used falls into three categories:

(1) Hot (cured) molded foams;

(2) Cold molded foams using TDI isocyanates; and

(3) Cold molded foams using MDI isocyanates.

It is interesting to note that the types of foams used vary considerably geographically. Thus, in North America, practically all molded foam is produced using TDI cold cure process while in Asia, there is a $50: 50$ split between the hot-cure and cold-cure foam processes, the latter predominantly using TDI. In Europe, the seat cushioning production is equally divided into the three types of foam.

The MDI cold cure process made its appearance in the late $1970 \mathrm{~s}$ and last year, 45,000 tons of cold cure foam based on MDI was produced worldwide. Since the hardness of MDI-based foams can be more easily adjusted by changes in the isocyanate index, they are ideally suited for the production of dual hardness foams. This fact, combined with environmental factors such as the low vapor pressure of MDI as compared to TDI and the generally faster molding cycle for MDI-based foams, has led to inroads of the MDI cold cured foam into North America and Asia. 
The cold cured TDI foam process makes use of either $80 / 20$ or $65 / 35$ isomers of TDI in various forms, as prepolymers, in blends with polymeric MDI and as straight TDI. in 1990, $55 \%$ of all flexible molded foam for automotive seat cushioning (about 215,000 tons of foam) was produced using TDI. The obvious advantages of this type of foam is the superior blowing efficiency of the isocyanate which results in lower density and softer foams. The low viscosity of the reaction mixture results in good flow properties in the mold. The resulting foam has a very high open cell content making crushing of the foam unnecessary. These are some of the factors which led to the production of about 120,000 tons of automotive seat cushions in 1990 made by the hot-cure process.

An interesting development has been the thermoforming of polyurethane foam for headliners in motor vehicles. Thermoforming of PU foams can be carried out with flexible, semi-rigid, and rigid foams. These foams, designated as TF-foams ${ }^{9}$ ), are characterized by light weight (usually $30 \sim 40 \mathrm{~kg} / \mathrm{m}^{3}$ ), excellent sound absorption, relatively high thermal stability (ca. $130 \sim 145^{\circ} \mathrm{C}$ ), and efficient assembly methods.

The manufacture of foam blocks for use as TF-foams can be carried out either by the continuous slabstock technique or by a discontinuous foaming process in a foam mold. After postcuring, the foam blocks are trimmed and split to a desired sheet thickness. Since the mechanical strength of the TF foam alone is not sufficient for self-supporting headliners, sandwich structures are made with these foams using various reinforcements such as chopped fiberglass mats, glass/thermoplastic hybrid non-woven materials and "Colback", a spunbonded non-woven material consisting of a polyester core and a polyamide skin. Adhesives that are thermally formable are necessary to bond the components of the sandwich structure.
The pre-lamination method enables the manufacture of pre-fabricated, semi-finished sandwich structures by using thermoplastic adhesives, either in the form of hot melt films or powders. The stored sandwich sheets are then conveyed to the heating stations where they are pre-heated and then transported to the pressing stations using metal molds where the structures are thermoformed. The temperature in the center of the foam core should be about $180-200^{\circ} \mathrm{C}$ so as to be readily formable. After a mold time of about 20 seconds, the mold is opened and the molded headliner is transported to the trimming station.

The replacement of CFCs in flexible foam systems by $\mathrm{CO}_{2}\left(\mathrm{H}_{2} \mathrm{O}\right.$ blown$)$, especially in all MDI flexible automotive foams using high monomeric MDI (MMDI), has led to interesting findings with regard to the effect of $2,4^{\prime}-\mathrm{MDI}$ in the MMDI isocyanate on the physical properties of the resulting foams ${ }^{10)}$. It was found that increased levels of $2,4^{\prime}-\mathrm{MDI}$ reduces the minimum fill density, improves elongation while reducing tear resistance to some extent, and also reduces load-bearing at constant molded density. It also significantly closes the cell structure. However, this new type of MMDI is chracterized by improved blowing efficiency and a lower viscosity buildup which reflects in improved flowability. It has also been recognized that low levels of 2,4MMDI favor improved demold performance; hence, the 2,4'-MDI content must be carefully balanced with the level for optimum flowability. These all water blown foams also exhibit good fatigue performance and low CLD-40 losses when compared to CFC-blown systems.

Texaco has developed specially designed blends of primary amine-terminated polyethers, designated as "TEXADD" for the production of HR-flexible foams ${ }^{11)}$. It is obvious that no catalyst is required for the isocyanate-amine reaction, although a tertiary amine catalyst is still needed for the water-iso- 
Table 5 Test formulation for manufacturing of PUREA foam.

\begin{tabular}{lc}
\hline & pts by wt \\
TEXADD F1012*1 & 100 \\
SUPRASEC VM25*2 & 54 \\
Silicone surfactant & 1.5 \\
Amine catalyst & 0.1 \\
Water*3 & 4.0 \\
Carbon dioxide & 0.5 \\
\hline *1 Primary amine-terminated polyether produced by \\
Texaco. \\
*2 Modified MDI (24.3\% NCO) produced by ICI. \\
$* 3$ ca.100\% surplus of water is used in the formulation.
\end{tabular}

cyanate (blowing reaction). A typical formulation for a so-called "PUREA" foam is shown in Table 5. These foams are produced free of CFCs using a high pressure PU machine from Krauss-Maffei. Certain modifications had to be made in the machinery since this is a highly reactive system. In addition to the carbon dioxide, generated by the water-isocyanate reaction, pressurized $\mathrm{CO}_{2}$ is injected into the mixing head without rapid gas release since these polyether-amines have a tendency to "hold" the $\mathrm{CO}_{2}$ that is injected. Advantages for these HR-PUREA foams claimed are not only fast processing time but also improved physical properties, a reduction in the isocyanate consumption, and a reduction in the emission of isocyanates, CFCs, and amine catalysts.

An interesting approach to the production of PU integral skin foams without CFCs for use in headrests and crashpads was reported by Enichem-Montedipe ${ }^{12)}$. It consists of the use of a rotational molding technique and filling the internal volume with a conventional foam. This requires a low viscosity polyurethane system with controlled reactivity to quickly wet the surface of the mold. Once the skin has been formed, two methods can be used: the one-step or the two-step procedure. In the two-step method, the skin produced must be demolded and in a second low cost mold, the filling of the cavity is carried out with a conventional $\mathrm{CO}_{2}$ - blown foam.

In the one-step procedure, after the skin is produced, the filling foam is directly injected in the same carousel after a short time interval. In this case, the inserts must be placed before the injection of the skin system. The decision to use the one- or two-step procedure depends on the shape of the part to be produced. Important factors of using the rotational molding technique are a significant weight reduction as compared to the production of conventional integral skin parts and the absence of fogging problems since no plasticizers are being used in the formulation. In addition, there is no yellowing problem due to interaction between the two layers, the skin, and the foam. It is claimed that the investment costs for a new plant using this new technology is cheaper than for a conventional plant.

An amine-free catalyst system for automotive instrument panels was reported by ICI $^{13)}$. Discoloration is often encountered in this application when using either PVC slushmolded skins or ABS/PVC foils in contact with PU foams. The mechanism of discoloration of the PVC is recognized as being due to the extraction of $\mathrm{HCl}$ from the PVC by the tertiary amine catalyst in the semi-rigid foam formulation leading to the formation of conjugated double bonds giving rise to discoloration of the PVC skin.

Using the potassium salt of the half ester of maleic acid as the catalyst, amine-free semirigid foam systems were successfully employed for the manufacture of instrument panels. Its use greatly improved the staining and reduced the embrittlement of the decorative cover stock. However, a selected quality of PVC is still required to pass the severe heat aging tests.

Shepherd Chemical Company has independently developed an amine-free semirigid foam system using certain bimetallic carboxylates in combination with tin catalysts for use in automotive instrument panels covered 
with PVG or PVG containing skins ${ }^{13-A}$.

Asahi Glass Company ${ }^{14)}$ has produced high molecular weight polyether polyols in the molecular weight range of 8000 to 10,000 with very low unsaturation values employing a new catalyst. The use of these high molecular weight polyols in HR molded foams for automotive use has resulted, in general, in higher resilience, excellent vibration characteristics, and higher durability when compared to a comparable foam made with a conventional polyol of 6000 molecular weight. An important aspect with regard to the use of the high molecular weight polyols, is the possibility of reducing foam density by increasing the water ratio without changing the compression set, the comfort, or the durability of the seat.

\section{HIGH TEMPERATURE STRUCTURAL FOAMS}

High temperature resistant structural foams have become increasingly important in many industrial applications, notably in aircraft applications. Requirements for these structural foams include, in addition to high temperature resistance, high mechanical properties, i.e. high strength to weight ratio, and good dimensional stability and moisture resistance. Some of the most commonly used methods for the introduction of heat resistant

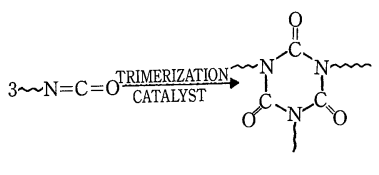

POLY(ISOCYANURATE)
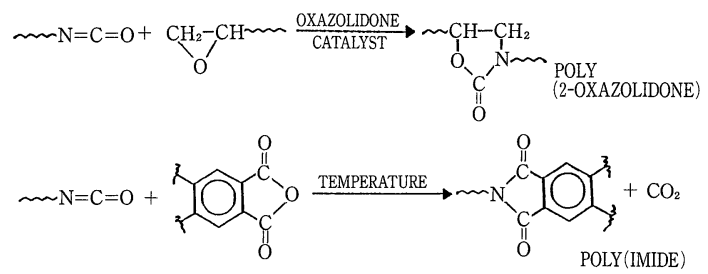

Fig. 1 Heat-resistant isocyanate-based polymers groups using isocyanate chemistry are the formation of isocyanurate, oxazolidone and imide groups (see Fig. 1). At Polymer Technologies, Inc. (PTI) of the University of Detroit Mercy, a comparative study of structural foams was carried out consisting of the following foam systems (see Table 6) ${ }^{15)}$.

Unmodified isocyanurate foams are very brittle as the result of their high crosslink density. Hence, in order to obtain good mechanical properties, polyols are introduced into commercial isocyanurate foams to form urethane-isocyanurate foams. However, the introduction of urethane groups decreases the heat stability of the isocyanurate foams. In order to increase the heat stability, urethane groups were partially or fully replaced by urea and oxazolidone groups. Oxazolidone isocyanurate structural foams were prepared by both the quasiprepolymer or one-shot methods. Since oxazolidone-modified isocyanurate foams at high

Table 6 Heat-Resistant Isocyante-Based Foams
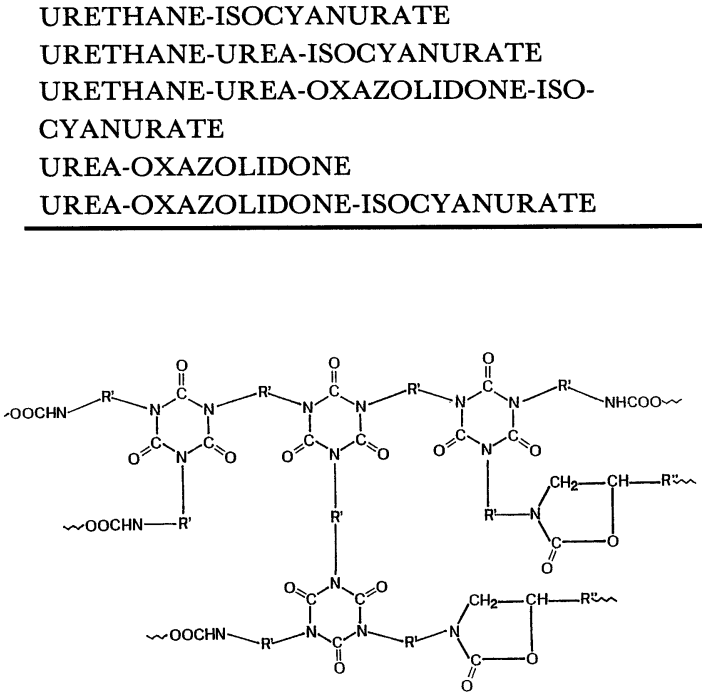

Fig. 2 Idealized structure of urethane-oxazolidoneisocyanurate polymer network:

-isocyanate index $=300$

- urethane/oxazolidone/isocyanurate molar ratio $=2 / 1 / 2$ 


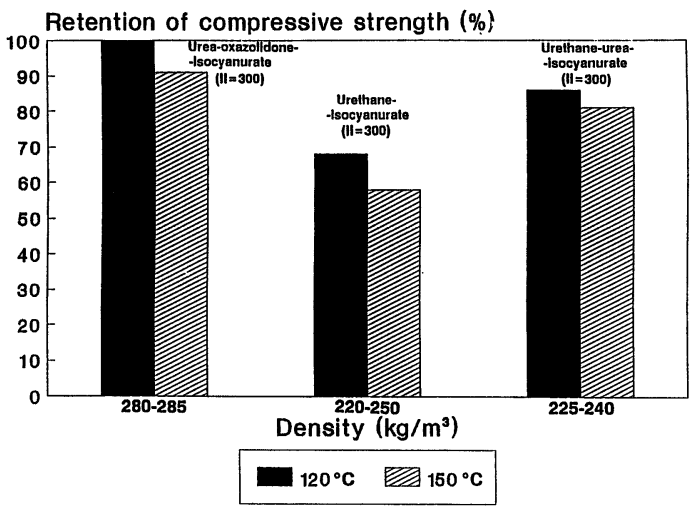

Fig. 3 Retention of compressive strength (\%) at elevated temperatures

isocyanate indices are very brittle, polyols were added to yield urethane-oxazolidone-isocyanurate foams. An idealized structure of this type of foam is shown in Fig. 2. It is obvious that if water $\left(\mathrm{CO}_{2}\right)$ is used as the sole or complimentary blowing agent, the resulting network would include urea groups.

A comparison of the retention of compressive strength of some of these structural foams at $120^{\circ}$ and $150^{\circ} \mathrm{C}$ is shown in Fig. 3. This investigation has shown that water-blown oxazolidone-isocyanurate foams have higher thermal resistance and better retention of compressive strength at elevated temperatures than the corresponding water-blown urethane-isocyanurate foams and that introduction of urea groups (water blowing) in urethane-isocyanurate foams also improves their thermal stability. In addition to high temperature resistance, these structural foams exhibit a high degree of foam isotropicity.

\section{NEW ELASTOMER DEVELOPMENTS}

High molecular weight polyether polyols made by using a double metal cyanide (DMC) catalyst, having very low unsaturation, which means a low monol content, designated by Olin as Poly-L polyols, have been used in the preparation of cast elastomers and thermoplastic elastomers (TPUs) ${ }^{16)}$. For instance, an elastomer system containing a 4000 molecular weight Poly-L diol, MDI and 1,4butanediol as chain extender (20\% hard segment) was compared with a system which contained a conventional PPG diol of 4000 mol.wt. instead of Poly diols. The resulting Poly-L-diol-based elastomers exhibited significantly higher tensile and tear strength and appreciably lower compression set. Thermoplastic elastomers based on Poly-L diols, MDI, and 1,4-BD could be extruded while the corresponding TPUs from a conventional polyol of the same molecular weight could not be processed. In addition, in comparing the physical properties of these TPUs after compression molding, the Poly-L diol based

Table 7 One-shot MDI thermoplastic elastomers extended with BDO.

\begin{tabular}{|c|c|c|c|c|c|c|c|c|}
\hline \multirow{2}{*}{ Polyol } & \multirow{2}{*}{$\begin{array}{l}\text { Unsat. } \\
\mathrm{meq} / \mathrm{g}\end{array}$} & \multirow{2}{*}{$\begin{array}{l}\% \text { Hard } \\
\text { Segment }\end{array}$} & \multirow{2}{*}{$\begin{array}{c}\text { Shore A } \\
\text { Hardness }\end{array}$} & \multirow{2}{*}{$\begin{array}{c}\text { Tenslle } \\
\text { Sterngth }\end{array}$} & \multirow{2}{*}{$\underset{\%}{\text { Elong. }}$} & \multicolumn{3}{|c|}{ Tenslle Modulus } \\
\hline & & & & & & $100 \%$ & $200 \%$ & $300 \%$ \\
\hline \multirow[t]{3}{*}{ POLY-G ${ }^{\oplus} 55-28$} & 0.061 & 10 & 41 & $179^{*}$ & 324 & 101 & 141 & 171 \\
\hline & & 15 & 54 & $535^{*}$ & 483 & 208 & 308 & 398 \\
\hline & & 20 & 65 & $562^{*}$ & 221 & 372 & - & - \\
\hline \multirow[t]{3}{*}{ POLY-L ${ }^{\mathrm{TM}} 255-28-1$} & 0.015 & 10 & 49 & 2006 & 1559 & 142 & 211 & 279 \\
\hline & & 15 & 61 & 3137 & 1252 & 448 & 608 & 754 \\
\hline & & 20 & 68 & 3456 & 1049 & 544 & 751 & 944 \\
\hline \multirow[t]{3}{*}{ POLY-L ${ }^{\mathrm{TM}} 255-16$} & 0.016 & 10 & 50 & $428^{*}$ & 502 & 161 & 236 & 305 \\
\hline & & 15 & 59 & 843 & 812 & 216 & 337 & 430 \\
\hline & & 20 & 64 & 1583 & 776 & 351 & 544 & 701 \\
\hline
\end{tabular}

* Tensile properties determined on compression molded plaques. 
elastomers exhibited significantly higher stressstrain properties and higher tensile modulus than the elastomer based on the conventional PPG diol of the same molecular weight as shown in Table 7.

In 1990, Olin also reported improved properties of polyurethane sealants based on these polyether polyols with low unsaturation.

UTI Chemicals Ltd. has developed a centripetal PU casting system for the production of temporary spare tires for cars ${ }^{17)}$. This "no-air" spare was developed in conjunction with the Goodyear Tire and Rubber Co. The tire weighs just 18 pounds (about $8.2 \mathrm{~kg}$ ) and is made by the centripetal PU casting technique incorporating a nylon belt to control the tire "growth" in use. The PU system is based on conventional polyether polyols and MDI-based prepolymers employing a proprietary catalyst/ chain extender/crosslinker package. A typical installation comprises a mixing and a dispensing unit, as in a conventional pressure machine, which supplies a six-station carousel fitted with multi-cavity molds. Each of these molds can be spun at up to several hundred revolutions per minute depending upon the degree of compaction and the desired type of product.

A typical machine cycle comprises a shot time of 4.5 seconds with a further 4.5 seconds per $60^{\circ}$ of movement, resulting in a total cycle time of just over 30 seconds, including mold release application. This spinning process is claimed to have very low scrap levels, citing wastes less than $1 \%$ and rejects below $0.5 \%$. It is also claimed that this process is "recyclable" by grinding the scrap and adding the granulate to other products. However, it remains to be seen whether the UTI process will become a commercial success.

One hundred percent solids aliphatic spray polyurea elastomer systems have been developed by Texaco ${ }^{18)}$. These systems are based upon the use of quasi-prepolymers from
Jeffamine polyetheramines and m-TMXDI which are reacted with a resin system consisting of polyetheramine and diamine chain extenders. Best results were obtained with 1,4diaminocyclohexane (1,4-DCH) and isophorone diamine (IPDA). Low molecular weight polyetheramines such as Jeffamine D230 (functionality 2, approx. mol. wt. 230) and Jeffamine T-403 (functionality 3, approx. mol. wt. 400) can also be used as chain extenders. Due to the fast reaction rates, two component spray equipment is required providing for impingement mixing by high pressure (Gusmer Corp.). No elastomer foaming was observed during periods of high humidity $(>85 \%)$. These spray systems are $100 \%$ solids which are processed at a $1: 1$ volume ratio. A wide hardness range can be obtained with these systems which is primarily dependent upon the composition of the soft polyetheramine block. These spray elastomers can be applied even at low temperatures $\left(-20^{\circ} \mathrm{C}\right)$; they have excellent physical properties, can be easily pigmented, and have wide formulation flexibility. Also, reinforcements can be easily incorporated, as in the aromatic spray polyurea systems which had previously been reported ${ }^{19)}$.

\section{RIM DEVELOPMENTS}

The total RIM market in 198920) was divided as follows:

$$
\begin{aligned}
& -43 \% \text { U.S.A. } \\
& -20 \% \text { Japan } \\
& -18 \% \text { Europe } \\
& -10 \% \text { Canada } \\
& -5.3 \% \text { Mexico } \\
& - \text { all other countries (3.1\% Pacific, } \\
& \text { 1.5\% South America) }
\end{aligned}
$$

While RIM and SRIM have made significant progress in Europe and in the United States, they are encountering serious competition from SMC and especially from thermoplastics, e.g. modified polypropylene, and various ther- 
moplastic alloys. An important advantage of thermoplastics is the relative ease of recycling. More recently, great emphasis has been placed on the recycling of RIM parts.

Light weight RIM composites for interior automotive substrates have been developed by Dow, designated as "SPECTRIMRL" series $^{20)}$. The process consists of preplacement of a PVC or another cloth surface material into the mold, followed by injection and foaming over a glass reinforcing mat or incorporating a short fiber reinforcement (typically $1 / 16^{\prime \prime}$ milled glass fibers) in the liquid resin (polyol component) to produce light weight, covered composite parts. Once removed from the mold, the parts are ready for assembly into the car.

Light weight RIM composites are produced either by open mold pour or by injection into closed molds. The open mold pour technique is most suitable for large complex shapes, preferably using a robot for reproducibility in the proper distribution of the urethane mixture.

The closed mold processing of light weight RIM composites offers the potential of reduced cycle time due to faster in-mold cure times because of the use of faster catalysts. It is also best suited for systems in which milled glass fibers are incorporated into the polyol component and thus avoiding the time needed to preplace the glass mat in the mold. Applications for these composites in automotive trim include door panels, instrument panels, parcel shelves and seat backs.

It is also interesting to note that these RIM composites can be ground (about 80 mesh) and can be incorporated (between 5 and $10 \%$ by weight of regrind) into virgin material with relatively minor changes in physical properties.

The advent of polyurea RIM systems has allowed high production cycles coupled with excellent mechanical properties and their high heat stability permits the on-line-painting of ex-

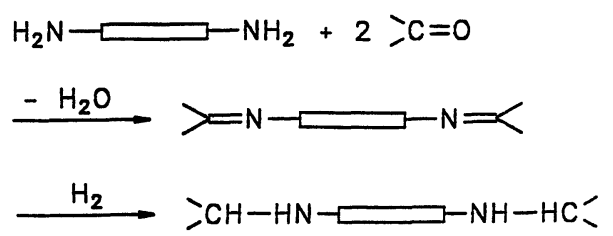

Fig. 4 Synthesis of secondary amino polyethers via hydrogenation of polyether ketimines

terior automotive body parts. However, the high reactivity of the primary aminopolyethers leads to rapid increase in viscosity, and, hence, shorter flow paths. A number of modifications of the original polyurea RIM systems were introduced by ICI, BASF, Bayer, and Dow by reducing the reactivity of the primary amine groups in polyetheramines by a number of different reactions, e.g. formation of carbamates by reaction with $\mathrm{CO}_{2}$, or formation of ketimines by reaction with ketones. BASF, for instance, introduced in 1989 a polyurea/amine system based on the polyether ketimine technology, termed Elastolit 4500.

Very recently, BASF ${ }^{21)}$ reported the preparation of secondary aminopolyethers by hydrogenation of the corresponding ketimines, as shown in Fig. 4. These secondary aminopolyethers exhibit significantly better flowability and mold filling characteristics although their heat distortion temperature (HDT) is somewhat lower than that of the primary amine based polyethers or the poly (urea-amide) systems. The secondary $\mathrm{C}_{7^{-}}$ amino-polyether system with MDI permits the use of a glass fiber filled IMR (internal mold release) system, termed Elastolit R4500/IF. Milled glass fiber systems $(15 \sim 25 \%$ glass fibers) exhibit good flow properties and excellent surface quality with somewhat reduced flex modulus and HDT.

\section{RECYGLING OF POLYURETHANES}

The problem of recycling or utilizing polyurethane scrap and waste products poses a 


\section{Scheme 1. RECYCLING OF POLYURETHANES}

I. MATERIAL REGYCLING

A. Use of Ground Stock or Granulates

1. Bonding of granulates, e.g. rug underlay

2. Fillers in foams, elastomers, RIM, composites, etc.

B. Thermo-Chemical Degradation

1. Pyrolysis

2. Hydrolysis

3. Glycolysis (Hydroglycolysis)

C. Hot-Stamping (Thermoforming)

II. ENERGY REGYCLING

formidable challenge for the polyurethane industry. In the United States, a program was launched by the PURRC, the Polyurethane Recycle and Recovery Council, sponsored by the Society of the Plastics Industry. The PURRC is aiming to recycle 500 million pounds (over 225,000 tons) representing about a quarter of all post-consumer polyurethane scrap by 1995 . The Council hopes to recover 68,000 tons of flexible foams, ca. 11,800 tons of rigid foams and ca. 1,800 tons of RIM products by 199522). There are other organizations, such as the MMPI and the Vehicle Recycling Partnership in Michigan.

In Germany, polyurethane raw material suppliers Bayer, BASF, and Dow Europe have teamed up with three processors involved in RIM recycling, namely, Phoenix, Pebra, and Gebruder Happich. This committee operates under the auspices of the Institute of Development of Recycling of Plastics, EWK, in Wiesbaden. This organization was established in 1990 by Bayer, BASF, and Hoechst. This committee will work both on already practiced methods such as high pressure, high temperature pressing of PU-RIM granulates, as well as on chemical or pyrolytic recycling of these products.

In general, the recycling of polyurethanes can be categorized into the following Scheme 1 .

One major area of the PU industry, flexi- ble foams used in upholstered furniture and mattresses, is already recycling $100 \%$ of manufacturing process scrap. In the U.S.A. alone, 280 million pounds of flexible foam scrap are chopped up and bonded with adhesives to produce high quality carpet padding, known as bonded underlay. In addition, some flexible foam scrap is used as loose fill for furniture cushioning and also in sound and energy absorbing composites.

It is noteworthy to point out that bonded underlay products have been so successful that the demand for flexible foam process scrap exceeds the supply in the United states. hence, it has been necessary for the bonded underlay manufacturers to import scrap from other countries to the tune of 54,000 tons, and thus contributing to global recycling efforts.

It is interesting that bonded foam is also finding use in soilless cultivation, so called hydroponics. It can serve as an alternate to rock wood as a growth medium. Unlike rock wool, it does not tend to become overly moist. Hydroponics is used in Europe to grow ornamental plants and grasses.

Flexible and semi-rigid polyurethanes can undergo the following processes:

(1) Pyrolysis

(2) Hydrolysis

(3) Glycolysis

The glycolysis process can also be applied 
to rigid foams and produces polyols that can be used in making foams with the same properties as with fresh polyols. The basic process is similar to a transesterification involving the carbamate (urethane) group with glycols, usually in the presence of suitable catalysts.

Recycling of $\mathrm{PU}$ foams by chemical methods has been studied by means of a number of methods. Hydrolysis with steam ${ }^{23)}$ and hydroglycolysis ${ }^{24), 25)}$ processes have been described for recycling flexible PU foams. These processes allow the recovery of the polyols but also form aromatic diamines which are more difficult to recycle. A number of investigators $^{26 \sim 28)}$ have found that waste glycolysis with diols form in a simple step products that are liquid at room temperature and terminated with active hydrogen-containing groups which can be used, when mixed with virgin polyols, in the production of new foams. However, most of these processes lead to products containing a fairly high amount of aromatic amines and their use could be somewhat hazardous.

Simioni et $\mathrm{al}^{29)}$ have developed a glycolysis process in which industrial rigid PU foam was treated with dipropylene glycol for three hours with a foam/glycol ratio of 55/100 and using an experimental catalyst. The use of selective catalysts for the transesterification reaction (reaction between the polymer carbamate groups and the glycol) to proceed at the lowest possible temperature is of utmost importance.
The properties of the recycled glycolysis product used either solely or in combination with virgin polyol are shown in Table 8 . As can be seen, the properties of these foams remain essentially the same as those of the foam made without any recycled material.

Bayer and Miles have developed a procedure for the recycling of flexible microcellular polyurethane foam ${ }^{30)}$. These foams are widely used in applications such as footwear, furniture, automotive, recreation, appliances, etc. Typical manufacturing scrap rates amount to 2 to $10 \%$. The process is very similar to conventional processing of thermoplastic polyurethanes (TPUs). The ground scrap is mixed together with an appropriate amount and type of virgin TPU and is then dried for two hours at $93-104^{\circ} \mathrm{C}$ using a desiccant-bed dehumidifier hopper drier. This mixture is then extruded in a single or twin screw extruder to continuous strand which is subsequently pelletized (see Fig. 5).

The polyurethane scrap at concentrations of $10-30 \%$ admixed with virgin TPU (Texin,

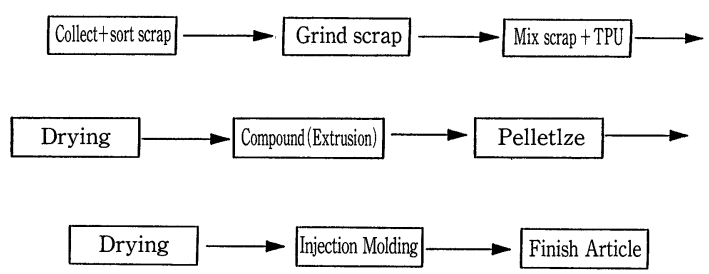

Fig. 5 Recycling process

Table 8 Properties of Foams Obtained from Blend of Virgin Polyol and Glycolysis Product.

\begin{tabular}{|c|c|c|c|c|c|c|}
\hline \multicolumn{7}{|c|}{ Foam Components (parts in weight): } \\
\hline Polyether polyol, sorbitol-based & 100 & 80 & 60 & 40 & 20 & 0 \\
\hline Glycolysis product & 0 & 20 & 40 & 60 & 80 & 100 \\
\hline \multicolumn{7}{|l|}{ Properties } \\
\hline $\operatorname{Density}\left(\mathrm{kg} / \mathrm{m}^{3}\right)$ & 28.0 & 27.8 & 27.4 & 28.0 & 27.9 & 27.5 \\
\hline Compression strength $(\mathrm{KPa})$ & 162 & 180 & 172 & 176 & 170 & 165 \\
\hline \multicolumn{7}{|l|}{ Dimensional Change $(\Delta 1 \%)$} \\
\hline $70^{\circ} \mathrm{G}, 95 \% \mathrm{RH}, 7$ days & 1.76 & 1.46 & 1.80 & 1.85 & 1.87 & 2.05 \\
\hline $70^{\circ} \mathrm{C}, 7$ days & 0.57 & 0.50 & 0.75 & 0.78 & 0.82 & 0.90 \\
\hline Thermal conductivity $(\mathrm{mW} / \mathrm{mK})$ & 19.8 & 19.4 & 19.6 & 20.3 & 20.0 & 19.2 \\
\hline
\end{tabular}


Miles) after molding exhibited physical properties very similar to those of virgin TPUs.

It was shown in this investigation that $\mathrm{PU}$ shoe sole production scrap could be used only with virgin PU, but also with other thermoplastics such as PVC and ABS with comparable good results.

The recycling of RIM scrap has been intensively studied in the United States, especially by Miles and Dow. Both processes involve grinding of the PU parts into small particles which can be used in certain proportions to produce new RIM parts or in the production of compression molded parts.

Dow $^{31)}$ favors a three-stream blending process consisting of A) isocyanate, B) a blend of ground scrap PU in polyol, and C) diethyltoluene diamine (DETDA) chain extender dispensing in a mixture with contains catalyst and internal mold release. The processing conditions are very similar to conventional RIM processing. A key for the successful use of this process is the economic grinding of the RIM scrap. It was found that a combination of a granulate and a pulverizer could yield material with a particle size in the $180 \sim 300$ $\mu \mathrm{m}$ range which is small enough to be readily incorporated into the RIM process mix.

Realizing that crosslinked RIM polyurethanes can be reshaped under heat and pressure, Rasshofer et $\mathrm{al}^{32)}$ have developed a thermoforming procedure which is similar to the deep drawing of sheet steel for car panels. This is possible because under these conditions, the soft segments form a matrix which permits orientation and reconfiguration of the "molten" hard segment domains. After cooling, the hard segment domains crystallize again and thus stabilize the newly formed products. The process is based upon utilizing production waste or used RIM parts which are chopped to a screen size of $2 \sim 3 \mathrm{~mm}$ by means of an appropriate cutting device followed by granulating at ambient temperatures. In
Table 9 Average energy content of various fuels.

\begin{tabular}{lc}
\hline Fuel & $\mathrm{MJ} / \mathrm{kg}$ \\
\hline RIM-Fascia Scrap & $27-28$ \\
Goal & $30-33$ \\
\#2 Fuel Oil & $42-43$ \\
\#6 Fuel Oil & $39-40$ \\
Methane & 52.5 \\
\hline
\end{tabular}

preparation for the compression molding, the granules are preheated in an oven at 140$150^{\circ} \mathrm{C}$ for one to three minutes and are then transferred into a steel tool with shear edges. Compression molding is carried out at 180 $190^{\circ} \mathrm{C}$ for one to three minutes at a specific mold pressure of $\geq 350 \mathrm{bar}$. The recombination and extent of unification of granules are the main factors for the maintenance of properties of the compression molded parts. The compression molding method for the recycling of RIM waste permits the production of articles which retain a good proportion of the properties of the original RIM materials.

Another important method for utilization of polyurethane parts is energy recovery by incineration. In one particularly noteworthy cooperative study by the Mobay Corporation (now Miles, Inc.) and Dow Chemical USA, polyurethane-urea IM process scrap was subjected to three different waste to energy systems. The goals of this study were:

(1) Establish material handling parameters.

(2) Evaluate and compare waste-to-energy systems of different designs.

(3) Define process conditions which yield combustion gases and solid residues meeting regulatory requirements.

(4) Quantify energy recovery.

These trials were carried out in a Mobay fluid bed combustor, a Mobay mass burning unit, and a Dow Freeport rotary kiln combustor. Trials were made with pure RIM production scrap, as well as using RIM as the fuel source to combust waste/water sludge. Some 
size reduction was necessary to feed RIM scrap successfully using existing material handling systems. All three combustor systems were suitable for handling RIM yielding in all cases emissions which were within EPA guidelines. It is also significant that RIM does not generate any $\mathrm{SO}_{2}$ and produces lower $\mathrm{CO}$ emissions per unit steam as compared to natural gas, fuel oil, or coal. Also, the $\mathrm{NO}_{2}$ emissions were less than $50 \%$ of the $\mathrm{NO}_{2}$ emissions from fuel oil or coal. These trials have demonsstrated that energy recovery from RIM waste for steam generation can be carried out successfully in at least three different types of combustors. RIM scrap has essentially the same fuel value as coal and RIM scrap could replace coal or $70 \sim 75 \%$ of fuel oil (see Table 9). Therefore, RIM scrap can be considered a valuable fuel source which should not be landfilled.

Waste to energy conversion, which is endorsed by the EPA as part of its balanced approach to waste management, achieves two goals:

(1) Waste reduction, and

(2) Less dependence on fossil fuels.

Both material recycling and energy recycling will undoubtedly be refined within the next few years using improved processes which are friendly to the environment.

\section{GONGLUSIONS}

These are but some of the recent developments in the polyurethane industry; there are many other exciting developments in polyurethane fields such as coatings, adhesives, sealants, composites, medical applications, etc.

Despite the various challenges which the polyurethane industry faces today, and in the days to come, the growth of the industry will continue worldwide, and it will contribute to improvements in the standard of living and the quality of life for everyone.

\section{References}

1) Reen, R. R.: Polyurethanes World Congress, SPI/ISOPA, Nice, France, Sept. 1991, p. 7.

2) Taverna, M. and Hufnagel, L.: ibid., p. 141.

3) Krueger, D. C. and Reichel, C. J.: ibid., p. 220.

4) Schutz, C.: UTECH 90, The Hague, Netherlands, April 1990, p. 20.

5) Wallaeys, B., DeSchryver, P. and Cop, R.: Polyurethanes World Congress, SPI/ISOPA, Nice, France, Sept. 1991, p. 63.

6) Lamberts, W. M.: ibid., p. 734.

7) Volkert, O.: ibid p. 740.

8) Schneider, H. G., Brock, M., Herrmann, M. and Wolf, K. D.: ibid., p. 108.

9) Schmutzer, K., Jung, L., Schlotterbeck, D. G. and Lutter, H. D.: ibid., p. 266.

10) Thoen, J. Elwell, R., Sewell, R., Broos, R., Pellacami, L., Pedroni, L. and Bergianti, G.: ibid., p. 100.

11) Humbert, H. and Klockemann, W.: ibid., p. 117.

12) Bianchin, E., Benetti, E., Andreola, R. and Vulcarenghi, A.: ibid., p. 430.

13) Christfreund, A., Huygens, E. and Eling, B.: ibid., p. 272.

13-A) Arenivar, J. D., Frisch, K. C., Wong, S., Wang, S. and Klempner, D.: UTECH '92, The Hague, The Netherlands, March 31-April 2, 1992, p. 161.

14) Hatano, S., Yasuda, N., Hayashida, S., Kunii, N., Takeyasu, H. and Kozawa, S.: ibid., p. 112.

15) Frisch, K. C., Sendijarevic, V., Sendijarevic, A., Lekovic, H., Kresta, J. E., Klempner, D., Hunter, L. and Banuk, R.: ibid., p. 850.

16) Smith, C. P., Reisch, J. W. and O'Connor, J. M.: ibid., p. 313 .

17) Urethanes Technology, April/May, 1991, p. 4.

18) Primeaux II, D. J.: Polyurethanes World Congress, SPI/ISOPA, Nice, France, Sept. 1991, p. 473.

19) Primeaux II, D. J.: UTECH 90. The Hague, Netherlands, April 1991, p. 189.

20) Loux, J. J., DeGenova, R., Bernardi, H. E. and Weaver, L. B.: Polyurethanes World Congress, SPI/ISOPA, Nice, France, Sept. 1991, p. 278.

21) Maletzko, C., Becker, J., Schmidt, H. U. and 
Matzke, G.: ibid., p. 669.

22) Reed, D.: Urethanes Technology, April/May 1991, p. 23.

23) Gerlock, J. L., Braslaw, J., Mahoney, L. R. and Ferris, F. C.: J. Polym. Sci., Polym. Chem. $E d ., 18,541$ (1980).

24) Gerlock, J. L., Braslaw, J. and Zinbo, M.: Ind. Eng. Chem. Process Des. Dev., 23, 545 (1984).

25) Braslaw, J. and Gerlock, J. L.: Ind. Eng. Chem. Process Des. Dev., 23, 552 (1984).

26) Ulrich, H. Odinak, A. Tucker, B. and Sayigh, A. A. R.: Polym. Eng. Sci., 18, 884 (1978).

27) Ulrich, H., Tucker, B., Odinak, A. and Gamache, A. R.: J. Elast. and Plastics, 11, 208
(1979).

28) Simioni, F., Bisello, S. and Tavan, M.: Cell. Polym., 2, 281 (1983).

29) Simioni, F. Modesti, M. and Rienzi, S. A.: Proceedings of "Cellular Polymers" Conference, London, U.K., March 1991, RAPRA Technology Ltd.

30) Franyutti, S., Seifert, P. and Cloutier, O. H.: Polyurethanes World Congress, SPI/ISOPA, Nice, France, Sept. 1991, p. 698.

31) Morgan, R. E., Dean, G. H., Tabor, R. L. and Zawisza, M.: ibid., p. 653.

32) Rasshofer, W., Liman, U. and Wagner, J.: ibid., p. 636.

\section{和文要旨}

\section{ポリウレタン工業の最近の発展}

本資料は，1930年代に始まり現在では全世界で年間600万トンも生産されるほど成長したポリウ レタン工業の最近の発展についてまとめたものである。ポリウレタンは多くの分野で使用されてい るが，最近の問題点として，フルオロカーボンの使用規制，火災に際しての煙，燃焼性，ポリウレ タンの製造，使用に際しての安全性，廃棄物のリサイクルなぞが現われてきている．ここではこれ らの状況を考慮したらえで,

(1) フルオロカーボンの代替の現状と将来の展望

(2) 新しい発泡体の開発の状況

(3) 耐熱性ストラクチュラルフォーム

(4) 新しいウレタンェラストマーの開発状況

(5) RIM (反応射出成型)の現状と問題点

(6) ポリウレタンのリサイクル

について, 具体的に各国, 各社の研究開発状況, 新製品新グレードなどを代表的な物性データ, 配 合データを挙げながら説明している．特にアメリカ，ヨーロッパの状況について詳しく述べてい る.ただし，塗料，接着剤，シーラント，医用用途などについては紙数の関係上触れていない. 